\title{
DENDROCHRONOLOGICAL DATING OF ICONS FROM THE MUSEUM OF THE FOLK BUILDING IN SANOK
}

\author{
MAREK KRĄPIEC and JOANNA BARNIAK \\ AGH - University of Science and Technology, Faculty of Geology, \\ Geophysics and Environmental Protection, \\ 30-059 Cracow, Mickiewicza 30, Poland
}

\begin{abstract}
Dendrochronological analysis was carried out for 13 historic icons from the collection of the Museum of the Folk Building in Sanok, painted on fir and spruce boards. Eleven sequences of the annual growth rings produced from the analysed fir boards were absolutely dated against the fir dendrochronological standard for S Poland, constructed by E. Szychowska-Krapiec. Most of the analysed objects date back to the seventeenth and eighteenth centuries, only one board was dated to the midnineteenth century. The dendrochronological analyses carried out prove broad possibilities of dating objects of the iconographic art painted on panels from fir wood, originating from south-eastern Poland and adjacent areas.
\end{abstract}

Keywords: dendrochronology, painting-panel dating, icons, Abies alba, S Poland

\section{INTRODUCTION}

The traditional method of dating of the art objects is based on the stylistical analysis of the work, what sometimes proves to be insufficient. Repetitiveness of symbols and motifs in art hinders precise putting of the analysed work on the time scale. In such cases the dendrochronological method is turning out to be helpful. It allows for precise dating of felling the tree from which the painting panel was made.

For the first time the dendrochronological method was applied to determination of the age of works of art at the end of the 1960s. To the analysis were subjected paintings of such seventeenth-century masters as: Philips Wouwerman, Klaes Molenaer and Cornelis Dusart, who painted on oak panels (Bauch and Eckstein, 1970). Later investigations were focused on oak painting panels of some Dutch, German and English artists (Bauch, 1978; Bauch and Eckstein, 1981; Eckstein and Bauch, 1974; Fletcher, 1976; 1978 and 1980). The analyses of oak panels of Dutch masters (Rembrandt, Rubens) resulted in a floating chronology, which did not correlate with any of the oak standards existing at that time. The problem could

Corresponding author: M. Krapiec e-mail: mkrapiec@geol.agh.edu.pl be solved thanks to dendrochronological studies of objects of art and architecture from the Gdańsk Pomerania region. High convergence of the Gdańsk chronology with the Dutch one allowed for absolute dating of the latter and also confirmed substantial scale of the oakwood exportation from the Baltic Countries to Western Europe (Eckstein et al., 1986). In the following years a number of studies was carried out on paintings from various galleries, often precising dating of the art historians, and in some cases proving forgeries (Haneca et al., 2005; Klein, 1989; Klein and Ważny, 1991; Läänelaid and Nurske, 2006; Ważny, 2001; Zielski and Krąpiec, 2004).

In Poland, except the paintings of western masters made on oakwood panels, commonly encountered are icons, also painted on wooden boards. Earlier studies on icons from south-eastern Poland, so-called Carpathian icons, dealt with determination of the tree species of wood used for production of the panels and technique of making the background. Such studies were carried out on stylistically dated objects from the District Museum in Nowy Sacz and the Museum - Castle in Łańcut. The results obtained are pointing on wide usage of fir wood in the seventeenth and eighteenth centuries (Kosiorek and Ważny, 1997). Moreover, these authors carried out dendrochronological analyses of 36 icons, which resulted in absolute datings (Ważny, 2001). 


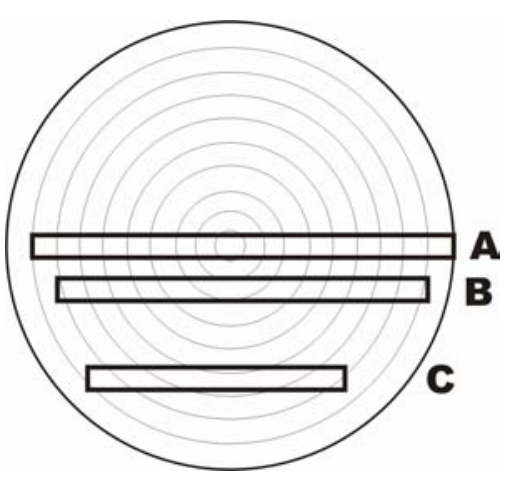

Fig. 1. Illustration of the way of cutting boards for panels of icons (Type A - radial board; Type $B$ - board tangential to internal increments; Type $\mathrm{C}$-tangential board).

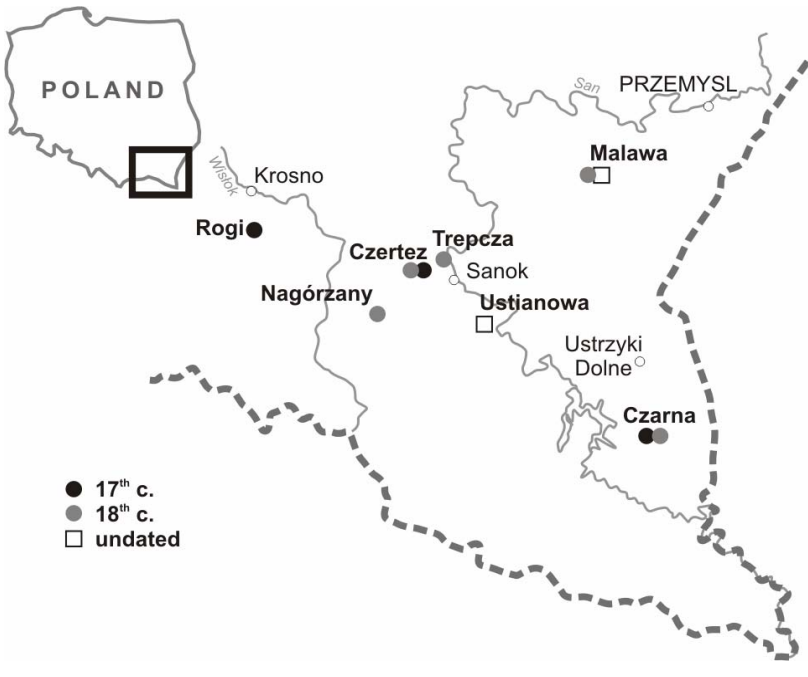

Fig. 2. Location of sacred objects from which came the dendrochronologically analysed icons.

Table 1. Additional information about the analysed icons and the painting technique and materials.

\begin{tabular}{|c|c|c|c|c|c|c|}
\hline No. & $\begin{array}{l}\text { Title } \\
\text { (inventory no.) }\end{array}$ & Origin site & $\begin{array}{c}\text { Panel size } \\
\text { (height } \mathrm{x} \text { width } \mathrm{x} \\
\text { thickness) } \\
(\mathrm{cm})\end{array}$ & Painting materials & $\begin{array}{l}\text { State of wood } \\
\text { preservation }\end{array}$ & $\begin{array}{l}\text { Type of- } \\
\text { board cut- } \\
\text { ting } \\
\text { (see Fig. 1) }\end{array}$ \\
\hline 1 & $\begin{array}{l}\text { Jesus Christ Redemptor } \\
(2739)\end{array}$ & $\begin{array}{c}\text { Ustianowa } \\
\text { (Bieszczady County) }\end{array}$ & $101 \times 69 \times 2.2$ & $\begin{array}{l}\text { chalk and glue } \\
\text { ground, distemper, } \\
\text { silver, varnish }\end{array}$ & $\begin{array}{l}\text { excellent, scarce } \\
\text { traces of insects }\end{array}$ & A \\
\hline 2 & $\begin{array}{l}\text { The Last Supper } \\
(11844)\end{array}$ & $\begin{array}{l}\text { unknown } \\
\text { (purchase) }\end{array}$ & $54 \times 102 \times 3$ & $\begin{array}{l}\text { chalk and glue } \\
\text { ground, distemper, } \\
\text { silver, gold, varnish }\end{array}$ & excellent & B \\
\hline 3 & $\begin{array}{l}\text { Deesis } \\
(14207)\end{array}$ & $\begin{array}{c}\text { Czerteż } \\
\text { (Sanok County) }\end{array}$ & $132.5 \times 73 \times 1.5$ & $\begin{array}{l}\text { chalk and glue } \\
\text { ground, oil, distem- } \\
\text { per, gold }\end{array}$ & $\begin{array}{l}\text { excellent, scarce } \\
\text { traces of insects }\end{array}$ & $B$ \\
\hline 4 & $\begin{array}{l}\text { Jesus Christ Redemptor } \\
\text { (3 567) }\end{array}$ & $\begin{array}{c}\text { Czarna } \\
\text { (Bieszczady County) }\end{array}$ & $110 \times 78.5 \times 2.5$ & $\begin{array}{l}\text { chalk and glue } \\
\text { ground, distemper, } \\
\text { silver, varnish }\end{array}$ & $\begin{array}{l}\text { good, partly burnt } \\
\text { board, filled } \\
\text { cracks }\end{array}$ & A \\
\hline 5 & $\begin{array}{l}\text { Saint Anna } \\
(14218)\end{array}$ & $\begin{array}{c}\text { Rogi } \\
\text { (Krosno County) }\end{array}$ & $110 \times 65.5 \times 3$ & $\begin{array}{l}\text { chalk and glue } \\
\text { ground, oil, gold }\end{array}$ & $\begin{array}{l}\text { good, traces of } \\
\text { insects }\end{array}$ & C \\
\hline 6 & $\begin{array}{l}\text { Apostles James the } \\
\text { Younger and Simon } \\
\text { (857) }\end{array}$ & $\begin{array}{c}\text { Nagórzany } \\
\text { (Sanok County) }\end{array}$ & $91 \times 74.5 \times 3.5$ & $\begin{array}{l}\text { chalk and glue } \\
\text { ground, oil, gold, } \\
\text { varnish }\end{array}$ & excellent & A \\
\hline 7 & $\begin{array}{l}\text { Entrance to Jerusalem } \\
(5929)\end{array}$ & $\begin{array}{l}\text { unknown } \\
\text { (purchase) }\end{array}$ & $37 \times 26 \times 1.5$ & $\begin{array}{l}\text { chalk and glue } \\
\text { ground, oil }\end{array}$ & excellent & B \\
\hline 8 & $\begin{array}{l}\text { Crucifixion (fragment) } \\
(1524)\end{array}$ & $\begin{array}{c}\text { Malawa } \\
\text { (Przemyśl County) }\end{array}$ & $72.5 \times 26.5 \times 2$ & $\begin{array}{l}\text { chalk and glue } \\
\text { ground, distemper, } \\
\text { silver, varnish }\end{array}$ & excellent & B \\
\hline 9 & $\begin{array}{l}\text { The Last Supper } \\
(14 \text { 194) }\end{array}$ & $\begin{array}{c}\text { Czerteż } \\
\text { (Sanok County) }\end{array}$ & $62 \times 75 \times 2$ & $\begin{array}{l}\text { chalk and glue } \\
\text { ground, oil, silver, } \\
\text { varnish }\end{array}$ & excellent & C \\
\hline 10 & $\begin{array}{l}\text { Jesus Christ Redemptor } \\
\text { (856) }\end{array}$ & $\begin{array}{c}\text { Nagórzany } \\
\text { (Sanok County) }\end{array}$ & $81.5 \times 60 \times 2$ & $\begin{array}{l}\text { chalk and glue } \\
\text { ground, distemper, } \\
\text { silver, varnish }\end{array}$ & good & C \\
\hline 11 & $\begin{array}{l}\text { Transfiguration } \\
(1603)\end{array}$ & $\begin{array}{c}\text { Malawa } \\
\text { (Przemyśl County) }\end{array}$ & $104 \times 65 \times 1.5$ & $\begin{array}{l}\text { chalk and glue } \\
\text { ground, distemper, } \\
\text { silver, varnish }\end{array}$ & $\begin{array}{l}\text { good, scarce } \\
\text { traces of insects, } \\
\text { cracks }\end{array}$ & C \\
\hline 12 & $\begin{array}{l}\text { Saint Dmitrij Soluński } \\
(1030)\end{array}$ & $\begin{array}{c}\text { Czarna } \\
\text { (Bieszczady County) }\end{array}$ & $805 \times 59 \times 2.5$ & $\begin{array}{l}\text { chalk and glue } \\
\text { ground, oil, silver, } \\
\text { gold, varnish }\end{array}$ & $\begin{array}{l}\text { good, scarce } \\
\text { traces of insects }\end{array}$ & C \\
\hline 13 & $\begin{array}{l}\text { Lady Mary in Veil } \\
(5900)\end{array}$ & $\begin{array}{c}\text { Trepcza } \\
\text { (Sanok County) }\end{array}$ & $157 \times 88 \times 2.5$ & $\begin{array}{l}\text { chalk and glue } \\
\text { ground, distemper, } \\
\text { silver, gold, varnish }\end{array}$ & $\begin{array}{l}\text { good, cracks, } \\
\text { scarce traces of } \\
\text { insects }\end{array}$ & C \\
\hline
\end{tabular}


The Museum of the Folk Building in Sanok stores an impressing collection of icons from the fifteenth to twentieth centuries, gathered in the $1960 \mathrm{~s}$, as a part of the action of protection the Orthodox-Church estate in the region of Podkarpacie. As dating of some specimens from that collection with traditional methods turned out to be difficult, the Conservation Studio of the Museum of the Folk Building in Sanok undertook co-operation with the Dendrochronological Laboratory at the AGH-UST, aimed at determination of ages of wooden panels with an independent method. The goal of this study was to apply the dendrochronological method to determination of the time of formation of selected historic icons from the collection of the Museum of the Folk Building in Sanok, for which the age determination on the basis of the stylistic analysis was ambiguous.

\section{WOODEN PANELS OF ICONS}

Wooden painting panels appeared in the WestEuropean art already in the antiquity. Moved aside in Middle Ages, they came back in the thirteenth century, together with the influence of the Byzantine culture; at first to Italy, then to the countries to the north from the Alps. In the sixteenth century, canvas started to be applied on a wide scale in Italy. In the North-European countries, e.g. Netherlands, however, painting on wooden panels was practiced until the nineteenth century, in spite of prices of high-quality wood rising from the seventeenth century (Kosiorek and Ważny, 1997).

In Poland, the Byzantine culture and the OrthodoxChurch art appeared and developed in the south-eastern part of the country in the first half of the fifteenth century. This was related to connecting to Poland the terrains of so-called Red Russia (Ruś Czerwona - regions of Sanok, Lviv, Przemyśl, and Halicz) by the king Kazimierz the Great, and to moving settlers of the Orthodox faith to these lands (Szczepkowski et al., 2004).

The Orthodox churches were usually decorated with individual icons as well as so-called iconostasis, i.e. a group of icons put between the main nave and the chancel. Depending on the wealth of the benefactor ordering the icon, native and readily available wood was used or more expensive timber was imported. For example, in Russia - lime, spruce, or pine timbers were preferred, whereas less accessible tree species, like oak or cypress occurred more rarely (Popova et al., 1998). In Poland fir, spruce, and lime were used most often.

At the choice of boards some principles were applied. The best was cohesive wood, with relatively small number of resin ducts and devoid of snags. Therefore, for painting icons boards from wood of such tree species were used as fir, spruce, cedar, as well as lime, oak, birch and beech; the boards had been appropriately long dried and prepared.

The boards were cut by no means at random. Most often radial planks were preferred, because of their low susceptibility to deformation as well as the opportunity of acquiring timber of its maximal width. On the contrary, a board cut tangentially was to a higher degree exposed to deformation. The studies of the Carpathian icons indicate that most of the analysed panels are boards cut in an intermediate way, i.e. tangentially to some internal treerings - see Fig. 1 (Kosiorek and Ważny, 1997). The boards forming a panel were joined together in such a way, that they could not bend towards the painting layer, what would have led to crushing the latter. Appropriate choice of the side of a painting panel guaranteed that even in the case of deformation of the panel, the painting layer would have only stretched, without having come off. Stability of the panels was assured by wooden slats (so-called schpongs), put in exactly fitting cuts on the back side of a panel (Onasch and Schnieper, 2002). This technique of making icons assured the stability of the panel, therefore even these oldest ones are preserved until present.

\section{MATERIAL}

Dendrochronological analyses were carried out on 13 icons, selected from the collection of the Museum of the Folk Building in Sanok. The majority of the icons came from sacred objects from the county Sanok and the neighbouring counties: Krosno, Bieszczady, and Prze
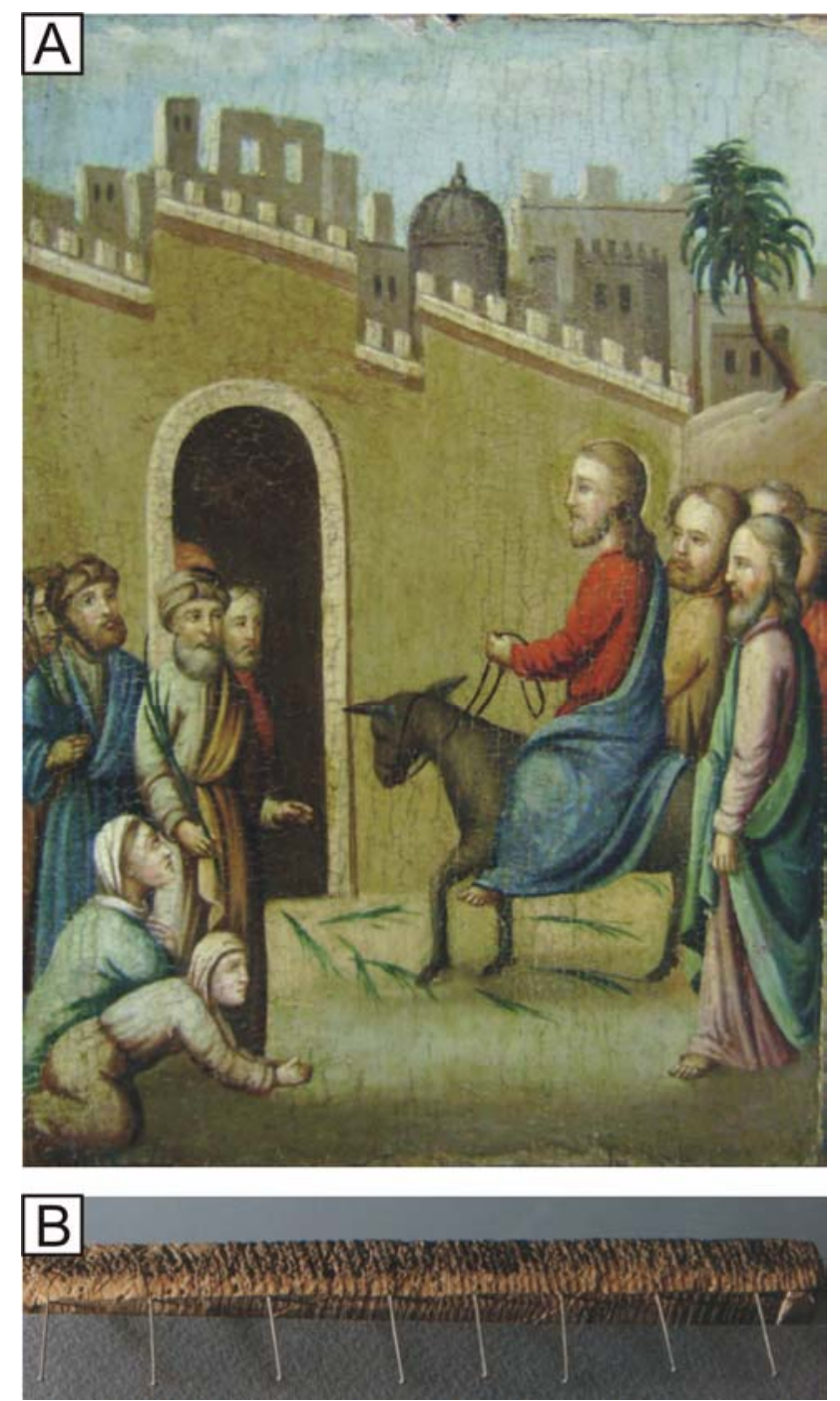

Fig. 3. Reproduction of the icon no 7 'Entrance to Jerusalem' (A) and preparation of the edge of the panel for measurements $(\mathbf{B})$. 


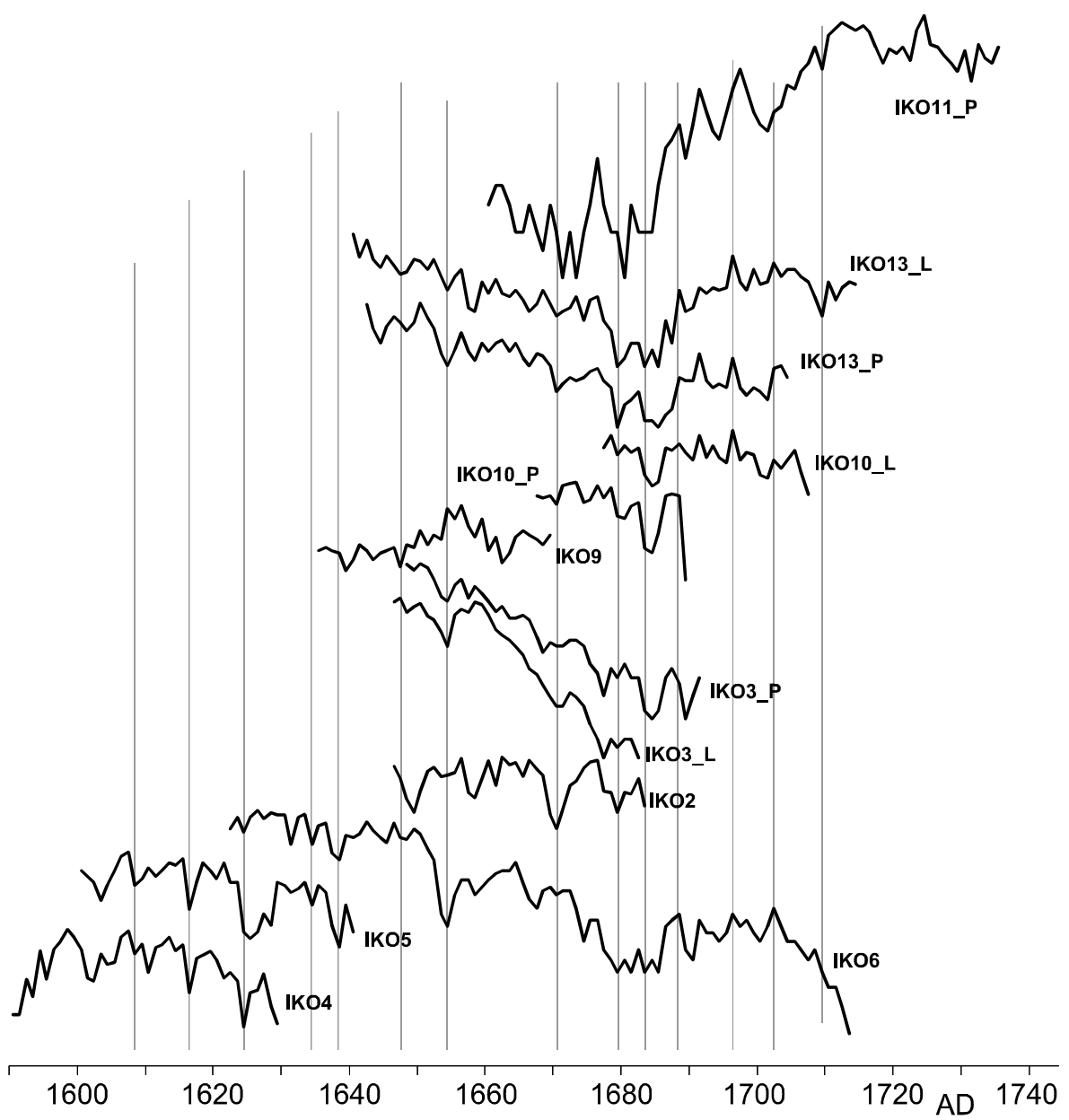

Fig. 4. Dendrochronological curves included in the chronology 3IKO_AO.

Table 2. Characteristics and dating of growth sequences of wooden panels of the selected objects from the collection of the Museum of the Folk Building in Sanok.

\begin{tabular}{|c|c|c|c|c|c|c|c|}
\hline No. & $\begin{array}{c}\text { Title } \\
\text { (inventory no.) }\end{array}$ & $\begin{array}{c}\text { Tree } \\
\text { species }\end{array}$ & $\begin{array}{l}\text { No. of } \\
\text { boards }\end{array}$ & $\begin{array}{l}\text { Laboratory } \\
\text { code }\end{array}$ & $\begin{array}{l}\text { No. of } \\
\text { tree rings }\end{array}$ & $\begin{array}{c}\text { Correlation with } \\
\text { 3ABSP1 } \\
\text { chronology, } \\
\text { t value } \\
\end{array}$ & $\begin{array}{l}\text { Dating of the } \\
\text { sequences }\end{array}$ \\
\hline 1 & $\begin{array}{l}\text { Jesus Christ Redemptor } \\
(2739)\end{array}$ & fir & 2 & $\begin{array}{l}\text { IK01_P } \\
\text { IK01_L }\end{array}$ & $\begin{array}{l}42 \\
38\end{array}$ & & \\
\hline 2 & $\begin{array}{l}\text { The Last Supper } \\
(11844)\end{array}$ & fir & 1 & IKO2 & 38 & 4.3 & $1646-1683$ \\
\hline 3 & $\begin{array}{l}\text { Deesis } \\
(14207)\end{array}$ & fir & 2 & $\begin{array}{l}\text { IKO3_L } \\
\text { IKO3_P }\end{array}$ & $\begin{array}{l}44 \\
37\end{array}$ & $\begin{array}{l}4.6 \\
4.2\end{array}$ & $\begin{array}{l}1648-1691 \\
1646-1682 \\
\end{array}$ \\
\hline 4 & $\begin{array}{l}\text { Jesus Christ Redemptor } \\
\text { (3 567) }\end{array}$ & fir & 2 & IKO4 & 40 & 4.1 & $1590-1629$ \\
\hline 5 & $\begin{array}{l}\text { Saint Anna } \\
(14218)\end{array}$ & fir & 2 & IKO5 & 41 & 4.7 & $1600-1640$ \\
\hline 6 & $\begin{array}{l}\text { Apostles James the Younger and Simon } \\
(857)\end{array}$ & fir & 2 & IKO6 & 92 & 8.3 & $1622-1713$ \\
\hline 7 & $\begin{array}{l}\text { Entrance to Jerusalem } \\
\text { (5 929) }\end{array}$ & fir & 1 & IKO7 & 80 & 4.3 & $1771-1850$ \\
\hline 8 & $\begin{array}{l}\text { Crucifixion (fragment) } \\
(1524)\end{array}$ & spruce & 1 & IKO8 & 36 & & \\
\hline 9 & $\begin{array}{l}\text { The Last Supper } \\
\text { (14 194) }\end{array}$ & fir & 2 & IKO9 & 67 & 8.3 & $1635-1701$ \\
\hline 10 & $\begin{array}{l}\text { Jesus Christ Redemptor } \\
(856)\end{array}$ & fir & 2 & $\begin{array}{l}\text { IKO10_L } \\
\text { IKO10_P }\end{array}$ & $\begin{array}{l}31 \\
23\end{array}$ & $\begin{array}{l}5.2 \\
3.8 \\
\end{array}$ & $\begin{array}{l}1677-1707 \\
1667-1689 \\
\end{array}$ \\
\hline 11 & $\begin{array}{l}\text { Transfiguration } \\
(1603)\end{array}$ & fir & 2 & $\begin{array}{l}\text { IKO11_L } \\
\text { IKO11_P }\end{array}$ & $\begin{array}{l}24 \\
76 \\
\end{array}$ & 4.5 & $1660-1735$ \\
\hline 12 & $\begin{array}{l}\text { Saint Dmitrij Soluński } \\
(1030)\end{array}$ & fir & 1 & IKO12 & 53 & 5.9 & 1727 - 1779 \\
\hline 13 & $\begin{array}{l}\text { Lady Mary in Veil } \\
(5900)\end{array}$ & fir & 2 & $\begin{array}{l}\text { IK013_L } \\
\text { IK013_P }\end{array}$ & $\begin{array}{l}75 \\
63 \\
\end{array}$ & $\begin{array}{l}8.1 \\
6.3 \\
\end{array}$ & $\begin{array}{l}1640-1714 \\
1642-1704 \\
\end{array}$ \\
\hline
\end{tabular}


myśl (Fig. 2).

Twelve of the investigated icons were painted on fir panels and the remaining one on a spruce panel. The wood of these panels was preserved in the excellent or at least satisfactory condition. Most of the panels (nine pieces) consist of two joined boards, strengthened from the back with schpongs. Out of 13 analysed icons, three were made on radial boards, four others on boards tangential to more or less internal increments, and the remaining six on boards cut out tangentially. Characteristics of the individual icons are presented in Table 1.

\section{METHODS}

In the case of art-historical objects it is inadvisable, practically impossible, to take samples for research in any way that would infringe the precious work. Therefore, tree-ring width measurements were made along the edges of the panels, having previously removed them from the frames.

Preparation of the icons for analyses consisted in appropriate preparation of transversal cross-sections of wood at the board margins to make the annual increments visible. For this purpose, thin layers of wood, 1-2 $\mathrm{mm}$ in thickness, were removed with preparation knives of Olfa type, until legible image of borders between tree-rings were achieved (Fig. 3).

The choice of the upper or lower margin of the panel, and later, of the part of the board suitable for measurements, depended on the state of preservation of the wood, possibilities of unveiling the increments, and the number of the latter. As the opposite edges of a board could differ as to the number of tree rings, the edges with their higher numbers were preferred. Such differences, sometimes reaching about ten to twenty increments, result from the orientation of side edges of the analysed boards, which may be different than the course of tree-rings.

The annual growth rings were counted and grouped in tens. At this preliminary stage of the analysis binocular microscope was used, in order to assure correct identification of the anatomical borders within zones of narrow rings. All the boards containing over 20 annual growths were selected for dendrochronological measurements.

Measurements of width of the annual rings with the accuracy of $0.1 \mathrm{~mm}$ were made in the Conservation Studio at the Museum of the Folk Building in Sanok with the help of a hand lens with the scale of the Eschenbach Company. The sequences of annual growth rings were computed in the Cracow format (AVR), dendrograms were plotted and compared with the standard chronologies using the package of programs TREE-RINGS (Krawczyk and Krapiec, 1995). In the course of investigations, standard techniques of dendrochronological dating were applied, presented and exhaustively described in numerous sources (Schweingruber, 1983 and 1988; Ważny, 2001; Zielski and Krapiec, 2004).

\section{RESULTS AND DISCUSSION}

Dendrochronological measurements of 13 panels of icons resulted in 18 relatively short sequences of annual growth rings: 17 of fir and one of spruce (Table 2). On the basis of the measurement data, dendrochronological curves were plotted and mutually correlated. Subsequently, those displaying the highest convergence were selected. These turned out to be the annual growth sequences of boards of icons nos 2, 3, 4, 5, 6, 9, 10,11, and 13 (Fig. 4). On the basis of those sequences, the average pattern 3IKO_A0, spanning 146 years, was determined.

For absolute dating, the average pattern and the remaining sequences were compared with the fir standard for Southern Poland - 3ABSP1, covering the period 1106-1998 AD (Szychowska-Krapiec, 2000). As a result, absolute dates were obtained for the average pattern as well as for two of the remaining sequences, not convergent with the average. Altogether 14 fir samples, coming from 11 icons, were dated (Fig. 5).

On the basis of all the absolutely dated sequences, the average curve 3IKO_A1 was constructed; 261 years long and covering the period 1590-1850 AD. It is, in fact, a local chronology, of which replication is, however, far from satisfactory in the first decades and in the last 140 years. In spite of that, it displays very high convergence with the Southern Poland chronology 3ABSP1 ( $t=12.5)$, as well as statistically significant values of similarity with fir standards for more distant regions: East Austria ( $\mathrm{t}=6.6$; Liebert et al., 1998) and Czech (t=4.1; Kyncl and Kyncl, 1996).

Dating of $76 \%$ fir sequences (13 out of 17) proves very high effectiveness of the dendrochronological method for age determination of the art masterpieces painted on fir panels. Such a result is in agreement with the observation of Szychowska-Krapiec (2000) indicate an extraordinarily strong dendrochronological signal of this tree species within the limits of its natural extent.

It should be remembered, that the date of felling the tree could not be unequivocally taken as the date of making the object. Attention should be paid to the fact that certain number of annual growth rings could be cut off during shaping of the panel. This possibility could be excluded only in the case when the timber retained its last, underbark ring, pointing on a complete sequence of tree rings until the end of growth of the tree. Such boards, however, were not encountered among the analysed icons.

When determining the age of an object, the time of seasoning wood should also be considered. The wood for painting panels had to be appropriately dried and prepared in order to minimize its subsequent 'working' which would led to cracking and destruction of the painting layer. The observations hitherto carried out indicate that the seasoning of fir wood usually took between several months and some years (Ważny, 2001).

Taking into account dendrochronological dating of the boards and the above remarks, determination of the time of making selected icons was attempted. The results of the analyses carried out indicate that the oldest analysed panel came from the 1630s (icon no 4). Somewhat younger is the panel of the icon no 5, apparently made in the 1640s. Most frequent are icons of which panels were dated to the last years of the seventeenth century and the first decades of the eighteenth century. Especially in cases of panels composed of two boards, the impact of the above-presented preparation is clearly marked. This 


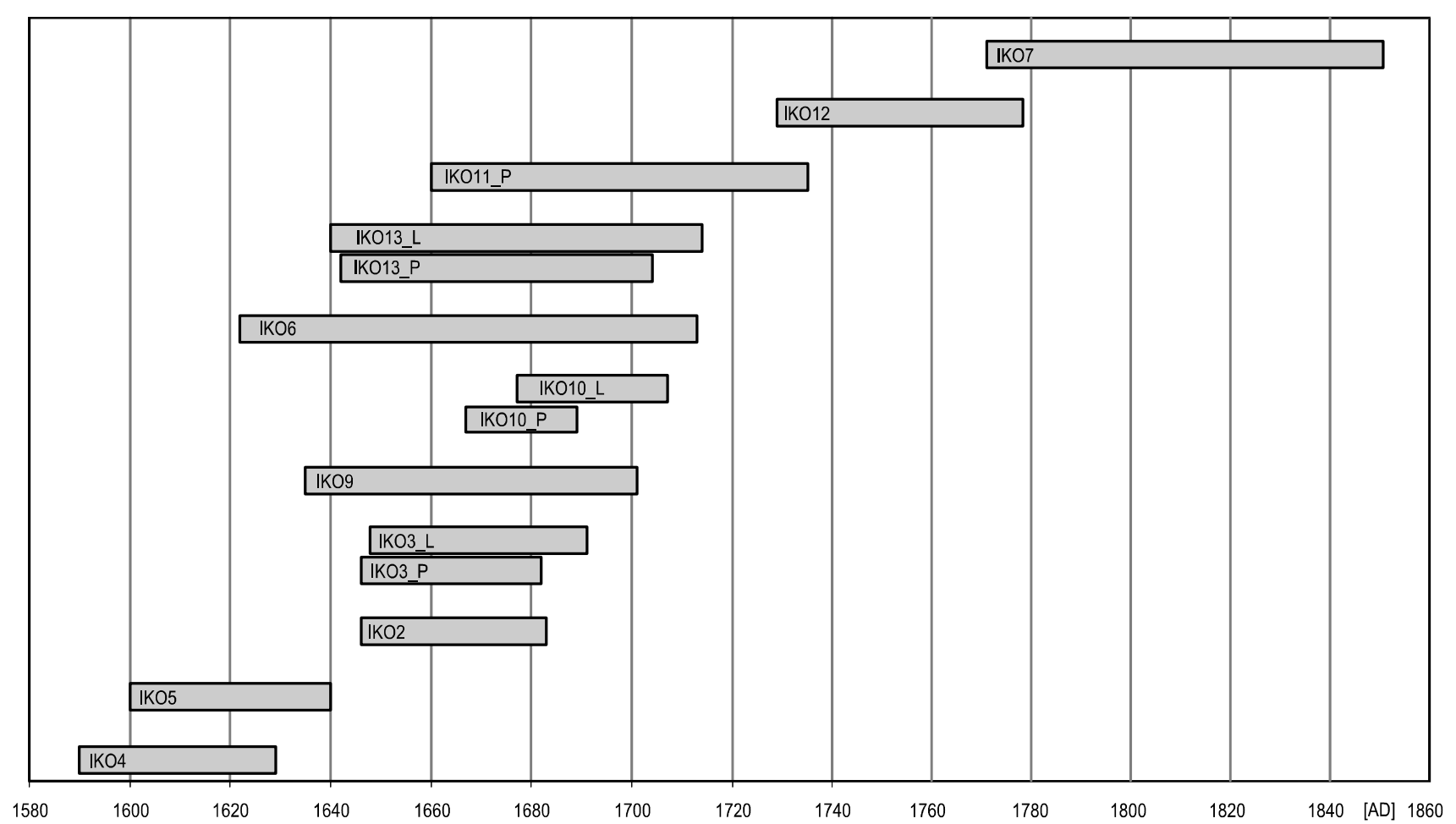

Fig. 5. Block-diagram of the dendrochronologically dated sequences of annual increments from the fir panels of the icons from the Museum of the Folk Building in Sanok.

may encompass several tree rings, what unequivocally indicates the necessity of measuring all boards forming a panel.

The remaining three icons turned out to be younger, which is in agreement with dating suggested by the stylistic analysis. Icon no 4, considered as coming from the first half of the eighteenth century was apparently made in the 1740s, whereas the icons nos 12 and 7, considered to be from the eighteenth or nineteenth century, were painted on panels made from wood cut down in the $1780 \mathrm{~s}$ (icon no 12) and in the 1850 s (icon no 7).

The attempts to determe the time of felling the trees from which came four boards forming the panels of objects nos 1 and 8 and one board of the object no 11 failed. This is connected with the relatively low number of annual growths in boards of these panels. Moreover, it should be noted, that icon no 8 was painted on a spruce panel which renders absolute dating much more difficult due to the lack of local standard for this tree species.

The dendrochronological method also allows to determine the region, from which the wood came. It is of particular importance in cases of so-called movable art masterpieces. The results of studies of Kosiorek and Ważny (1997) point out common usage of fir wood for making panels of icons in the seventeenth and eighteenth centuries. Till the nineteenth century the fir was a common tree species in the Carpathian forests (Hołowkiewicz, 1877). High convergence of the curve 3IKO_A1 with the regional fir standard also seems to indicate local wood as the material for painting panels. It can be expected, that in the whole region of Podkarpacie the schools of painting icons profited from readily avail- able and relatively cheap material from the nearby forests.

\section{CONCLUSIONS}

The results of the investigations carried out demonstrate high usefulness of the dendrochronological method for dating historic icons made on fir panels. This may be proved by the successful determination of the manufacture time of eleven objects out of thirteen selected for the analyses. Taking into consideration the limitations of the method (inability of accurate assessment of the time of seasoning the wood as well as of estimating the number of missing annual growth rings), it may be assumed that the obtained dating 'terminus post quem' should not differ from the time of making the object by more than a few, maximally several years.

\section{REFERENCES}

Bauch J, 1978. Dendrochronology applied to the dating Dutch, Flemish and German paintings. In: Fletcher JM, ed., Dendrochronology in Europe: principles, interpretations and applications to archaeology and history. B.A.R. International Series 51: 307-313.

Bauch J and Eckstein D, 1970. Dendrochronological Dating of Oak Panels of Dutch Seventeenth-Century Paintings. Studies in Conservation 15: 45-50.

Bauch J and Eckstein D, 1981. Woodbiological investigations on panels of Rembrandt paintings. Wood Science and Technology 15: 251263.

Eckstein D and Bauch J, 1974. Dendrochronologie und Kunstgeschichte-dargestellt an Gemälden holländischer und altdeutscher Malerei. Mitt. Deutsch. Dendrol. Ges. 67: 234-243 (in German).

Eckstein D, Ważny T, Bauch J and Klein P, 1986. New evidence for the dendrochronological dating of Netherlandish paintings. Nature 320: 465-466. 
Fletcher JM, 1976. A group of English royal portraits painted soon after 1513: a dendrochronological study. Studies in Conservation 21: 171-178.

Fletcher JM, 1978. Tree-ring analysis of panels, paintings and chests. In: Fletcher JM, ed., Dendrochronology in Europe: principles, interpretations and applications to archaeology and history. B.A.R. International Series 51: 303-306.

Fletcher JM, 1980. Tree ring dating of Tudor portraits. Proceedings of the Royal Institution of Great Britain 52: 81-104.

Haneca K, Ważny T, van Acker J and Beeckman H, 2005. Provenancing Baltic timber from art historical objects: success and limitations. Journal of Archaeological Science 32: 261-271.

Hołowkiewicz E, 1877. Flora leśna i przemysł drzewny Galicji. (Forest flora and timber industry in Galicia). Drukarnia W. Łozińki, Lwów, 67 pp (in Polish).

Klein P, 1989. Dendrochronological studies on oak panels of Rogier van der Weyden and his circle. In: Le dessin sous-jacent dans la peinture. Colloque VII, September 1987. Université Louvain-LaNeuve: 25-36.

Klein P and Ważny T, 1991. Dendrochronological Analyses of Paintings of Gdansk Painters of the $15^{\text {th }}$ to the $17^{\text {th }}$ Century. Dendrochronologia 9: 181-191.

Kosiorek A and Ważny T, 1997. Gatunki drewna stosowane w ikonach karpackich. (Wood species used in the Carpathian icons). Ochrona Zabytków 50(3): 315-320 (in Polish).

Krawczyk A and Krapiec M, 1995. Dendrochronologiczna baza danych. (Dendrochronological database). Mat. II Krajowej Konferencji: Komputerowe wspomaganie badań naukowych (Proceedings of II Polish Conference „Computers in Scientific Researches”): 247252. Wrocław (in Polish).

Kyncl J and Kyncl T, 1996. Dating of historical fir (Abies alba) wood in
Bohemia and Moravia. Dendrochronologia 14: 237-240

Läänelaid A and Nurkse A, 2006. Dating of a $17^{\text {th }}$ Century Paintings by Tree Rings of Baltic Oak. Baltic Forestry 12(1): 117-121.

Liebert S, Grabner M and Wimmer R, 1998. A 1000-year fir chronology for East-Austria. European Dendrochronology Workshop "Eurodendro-98" - Dendrochronology and Environmental Trends: 18-23, Kaunas.

Onasch K and Schnieper A, 2002. Ikony. Fakty i legendy. (Icons. Facts and Legends).Wyd. Arkady, Warszawa: 302 pp (in Polish).

Popova O, Smirnova E and Cortesi P, 1998. Ikony. Ikony różnych kręgów kulturowych od VI w. po czasy współczesne. (Icons. Icons from various cultures since the $\sigma^{\text {th }} c$. till present). Wyd. Arkady, Warszawa: 192 pp (in Polish).

Schweingruber FH, 1983. Der Jahrring. P Haup Verlag, Bern-Stuttgart: 234 pp (in German).

Schweingruber FH, 1988. Tree-rings. Basic and applications in dendrochronology. Reidel, Dortrecht: 276 pp.

Szczepkowski A, Ginalski J, Kraczkowski M and Szulc W, 2004. Ikona karpacka. Przewodnik po wystawie. (Carpathian icon. Guidebook of the exposition). Muzeum Budownictwa Ludowego, Sanok: 47 pp (in Polish).

Szychowska-Krapiec E, 2000. Późnoholoceński standard dendrochronologiczny dla jodły Abies alba Mill. z obszaru południowej Polski. (The Late Holocene master chronology of fir Abies alba Mill. from southern Poland). Zeszyty Naukowe AGH, Geologia 26(2): $173-$ 299 (in Polish).

Ważny T, 2001. Dendrochronologia obiektów zabytkowych $w$ Polsce (Dendrochronology of historic objects in Poland). Muzeum Archeologiczne, Gdańsk: 137 pp (in Polish).

Zielski A and Krapiec M, 2004. Dendrochronologia (Dendrochronology). PWN Warszawa: 328 pp (in Polish) 